\title{
RESEARCH ARTICLE Preliminary studies on the in situ prevention of food spoilage fungi using antifungal Lactic acid bacteria
}

Preliminary study on the in situ prevention of food spoilage fungi using antifungal Lactic acid bacteria Srileka Chinnaiyan and Vijila Kenas*

Department of Agricultural Microbiology, Tamil Nadu Agricultural University, Coimbatore- 641003 *Corresponding author vijiladauphin@yahoo.co.in

\section{ABSTRACT}

Food loss is a major threat in the world and one-third of the food produced for human consumption are wasted. Many fungal species cause loss of food/raw materials like grains, fruits and vegetables throughout the world. Chemical preservatives and fungicides when used in food have negative impacts on health and the environment. Biopreservatives such as lactic acid bacteria (LAB) are effective, safe, biodegradable and have additional health benefits. The focus of this research is to survey the occurrence of native lactic acid bacteria with antifungal activity in various food sources and to obtain a potential lactic acid bacterial isolate for strategic application to control fungal pathogen in food products. In the present study, the population of lactic acid bacteria were about $10^{4}$ to $10^{5}$ cells in all food samples. Sixty isolates of lactic acid bacteria were obtained from samples collected. Of these, 21 exhibited inhibition towards the growth of Fusarium oxysporum and 13 isolates towards $A$. flavus. Ten of the total isolates exhibited inhibition towards both the test fungi. Based on potential of antifungal activity in the dual plate technique, six isolates were selected and subjected to fungal growth inhibition analysis using microplate. Of these six isolates, the isolate LABT3 showed the highest inhibition percentage (\%) against both the target fungi. The isolate was tested for its growth and maximum growth was noted at $48 \mathrm{~h}$ and $\mathrm{pH}$ at this period was5.16.

Keywords: Lactic acid bacteria; A. flavus; F. oxysporum; Fungal growth inhibition; Food spoilage

\section{INTRODUCTION}

Postharvest loss refers to significant food loss in the postharvest system (Lucia, 1994). Life style change had made the food industry flourish and processed foods are ruling the food market. Raw agricultural products and processed food products like fruit juices carry many spoilage bacteria and fungi. In India, the production of raw food materials is about 450 million tonnes of which $10 \%$ postharvest loss is in cereals and pulses, $20 \%$ in semi perishable and $25 \%$ in products like milk, meat, fish and egg (Rajasri et al. , 2014).

Fungi are known as one of the important spoilage organisms in food (Pitt and Hocking, 2009). The Food and Agricultural Organization reported that $25 \%$ of worldwide crops were contaminated by mycotoxin producing filamentous fungi like Fusarium, Aspergillus, Penicillium (Joint et al. , 2002). To eliminate these mycotoxins, postharvest detoxification strategies like physical, chemical and biological strategies have been reported (Jard et al. , 2011).

The excessive use of fungal detoxicants leads to the development of a resistant pathogen population and a consequent increase in toxic residue in food products. Also, consumer preference for natural antimicrobial compounds of plant and animal origin has led to the search for bio preservatives to prevent or control fungal spoilage in raw and processed foods (de Souza Sant'Ana et al., 2008; Walter et al., 2015).

Lactic acid bacteria (LAB) have attained Generally Recognized As Safestatus (Stiles, 1996) for foodapplication. Antifungal metabolites produced by members of lactic acid bacteria are lactic acid, acetic acid, formic acid, propionic acid, fatty acid, hydrogen peroxide, diacetyl, cyclic dipeptides, reuterin and phenolic compounds have been documented (Crowley et al. , 2013). The cell-free supernatant of Lactobacillus sp. from the buttermilk of raw buffalo milk had strong and broad antimicrobial activity against both harmful bacteria and toxigenic fungi such as Aspergillus parasiticus, $A$. flavus and $A$. carbonariuis and also inhibited aflatoxin and ochratoxin production (Shehata et al., 2019). The LAB isolated from fermented beverages were identified as L. plantarum, L. paracasei and L. pentosus showed strong antifungal activity against Colletotrichum gloeosporioides (Barrios- 
Roblero et al., 2019). Preservation of tomatoes with the cell-free supernatant of $L$. plantarum reduced the fungal spore load (Luz et al., 2020). In the present study, LAB isolates with potential antifungal properties suitable for in situ application in food were screened.

\section{MATERIAL AND METHODS}

\section{Collection of sample}

The samples of curd and idly batter, fermented in the household for $12 \mathrm{~h}$, fresh tomato and cabbage collected from Uzhavar sandhai and paddy grains collected from Central Farm, Tamil Nadu Agricultural University, Coimbatore were used. The samples were transferred to the laboratory in sterile plastic bags. Samples were not stored.

\section{Fungal cultures}

The fungal cultures of Aspergillus flavus AS4 (MT830910) and Fusarium oxysporum FOS CB1 (MN999964) were obtained from the Department of Plant Pathology, Tamil Nadu Agricultural University, Coimbatore. The fungal cultures were sub-cultured on Potato Dextrose Agar (PDA) media by disc method. Fungi were incubated at $25 \pm 2{ }^{\circ} \mathrm{C}$ for $4-5$ days.

\section{Preparation of samples}

Approximately $5 \mathrm{~g}$ of paddy grains were soaked in $25 \mathrm{~mL}$ sterile water and incubated for $12 \mathrm{~h}$ at $28^{\circ} \mathrm{C}$. The cabbage was cut into $1-2 \mathrm{~cm}$ pieces and $180 \mathrm{~g}$ was taken in a sterile airtight glass container and added with 2 $\%(\mathrm{w} / \mathrm{v})$ salt, mixed and pressed tightly without the air space and incubated at $28^{\circ} \mathrm{C}$ for 5 days (Lee et al., 2006). Tomatoes were cut into pieces and homogenized in the stomacher (Bag Mixer $₫$, Interscience, France) for 2 min (Elmabrok et al., 2013).

\section{Isolation of $L A B$ from the prepared samples}

For the isolation of LAB, $1 \mathrm{~mL}$ of curd, $1 \mathrm{~g}$ of idly batter, $1 \mathrm{~mL}$ of homogenized tomato sample, $1 \mathrm{~mL}$ of soaked water of paddy grains and $1 \mathrm{~mL}$ of fermented liquid of cabbage were taken. Appropriate dilutions were plated in MRS (de Man Rogosa Sharpe) agar plates (De Man et al., 1960) by pour plate technique and the plates were incubated at $37^{\circ} \mathrm{C}$ for $48 \mathrm{~h}$. After incubation, the various morphological colonies were selected and purified. All the isolates were tested for Gram reaction and catalase test.

\section{Screening of $L A B$ isolates for antifungal activity}

$\angle A B$ isolates were screened for antifungal activity by dual plate technique (Gerbaldo et al., 2012). The isolates were seeded until covering one-third of the surface of MRS agar plates and incubated at $37^{\circ} \mathrm{C}$ for $48 \mathrm{~h}$. A PDA plug with $A$. flavus and $F$. oxysporum was placed on the center of the free surface of the above LAB seeded MRS agar plates. The plates were incubated aerobically at $25 \pm 2{ }^{\circ} \mathrm{C}$ for 5 days. The mold growth was observed daily and inhibition distance was recorded.

\section{Microplate fungal growth inhibition analysis of $L A B$ isolates}

Preparation of fungal spore suspension

The fungal spores were cultured in PDA plates. The fungal spores were collected by flooding $5 \mathrm{~mL}$ of sterile distilled water on fully grown pure $A$. flavus and $F$. oxysporum plates. The sterile water with spores were collected as spore suspension. An appropriate dilution was made by serial dilution technique. Then the spores of both fungal culture was counted in hemocytometer and recorded as $4 \times 10^{5}$ spores mL-1 for $A$. flavus and $3 \times 10^{5}$ spores $\mathrm{mL}^{-1}$ for $F$. oxysporum.

\section{Microplate fungal growth inhibition analysis}

One percent inoculum containing $10^{7}$ cells mL-1 of $24 \mathrm{~h}$ old culture of $6 \mathrm{LAB}$ isolates was inoculated in MRS broth, incubated at $37^{\circ} \mathrm{C}$ in shaken condition. After $48 \mathrm{~h}$ of incubation, bacterial biomass was separated by centrifugation at $8000 \mathrm{rpm}$ for $15 \mathrm{~min}$. The $10 \mu \mathrm{l}$ of spore suspension with $160 \mu \mathrm{l}$ of cell-free supernatant (CFS) of $L A B$ isolates were taken in sterile microtiter plate; $10 \mu \mathrm{l}$ of spore suspension with $160 \mu \mathrm{l}$ of sterile MRS broth was maintained as control. The microtiter plate was incubated at $25 \pm 2{ }^{\circ} \mathrm{C}$ for $72 \mathrm{~h}$. The antifungal activity of $\mathrm{LAB}$ isolates was evaluated by reading absorbance at $\mathrm{OD}_{490 \mathrm{~nm}}$ for $A$. flavus and $\mathrm{OD}_{530 \mathrm{~nm}}$ for $F$. oxysporum using a microplate reader (Synergy HTX). The results were represented in percentage and calculated by using the following formula (Rugirello et al., 2019),

Percentage of fungal growth inhibition $=\{$ (Control - Treatment $) /$ Control $\} \times 100$

For statistical analysis, ANOVA followed by Duncan test was performed by using SPSS assessed using $p<0.05$. The best performing isolate was identified by analyzing within the isolates for each target fungi and being significant from each other. 


\section{Growth characteristics of antifungal LAB isolate}

The LAB isolate LABT 3 was inoculated in $100 \mathrm{~mL}$ sterile MRS broth with initial pH of 6.4 and incubated at $37^{\circ} \mathrm{C}$ for $24 \mathrm{~h}$. The $1 \%\left(10^{6}\right.$ cells $\left.\mathrm{mL}^{-1}\right)$ inoculum was used for the studies. The growth of cells was expressed in log cfu $\mathrm{mL}^{-1}$. The viable cell population of the culture at different time intervals was recorded by plating the appropriate dilutions at periodical intervals on MRS agar plates. The cell-free supernatant was collected by centrifugation at $8,000 \mathrm{rpm}$ for $15 \mathrm{~min}$ and $\mathrm{pH}$ of the culture broth was recorded by using $\mathrm{pH}$ meter $(\mu \mathrm{pH}$ System 361 , Systronics, India).

\section{RESULTS AND DISCUSSION}

\section{Occurrence of $L A B$ in agricultural products}

Lactic acid bacteria (LAB) are ubiquitously present in most food systems. The presence of $L A B$ in raw and fermented agricultural products and their role in bio preservation were documented (Schnurer and Magnusson, 2005). In our study, the samples of soaked water of stored paddy grains, idly batter, tomato, fermented cabbage and curd were found to carry a good population of LAB. In general, the fermentation process has increased the population of LAB. The population of lactic acid bacteria was high in fermented food samples such as curd $\left(83.5 \times 10^{5}\right)$, idly batter $\left(75.2 \times 10^{5}\right)$, fermented cabbage $\left(62.5 \times 10^{5}\right)$ than nonfermented food samples such as fresh tomato $\left(38.6 \times 10^{4}\right)$ and paddy grains $\left(28.3 \times 10^{4}\right)$ (Table 1$)$. The colony morphology of the $L A B$ isolates from the samples varied to a great extent in terms of colour from white, pale white, creamy and pale yellow, different forms of elevation and edges as convex, flat, raised and entire. A total 60 isolates were taken on the basis of colony morphology. All the isolates were positive to Gram staining reaction and catalasenegative. Of these 60 isolates, $51.66 \%$ were cocci and $48.33 \%$ were bacilli. The majority of the LAB isolates obtained from traditional butter were bacilli (52.34\%) compared to cocci (47.66\%) (Bettache et al., 2012)., However, LAB isolates obtained from fermented rice were found to be cocci and diplococci than bacilli (Jeygowri et al., 2015). The production of exopolysaccharide was observed in most LAB isolates obtained from soaked water of paddy grains.

\section{Antifungal activity of $L A B$ isolates}

Plethora of papers documented the use of $L A B$ as antifungal agents for fungal growth inhibition and detoxification of mycotoxins (Gourama and Bullerman, 1955; Muhialdin et al., 2020). The sixty LAB isolates obtained in this study were screened for antifungal activity by dual plate technique. Among the 60 isolates, 21 isolates exhibited inhibition of growth of $F$. oxysporum and 13 isolates inhibited $A$. flavus. Both the fungi were inhibited by 10 of the total 60 isolates (Table 2). The fungal inhibition by LAB isolates was presented in Figure 1. The isolates of paddy grains showed a similar level of inhibitory activity against both the test fungi (Figure 2). Guo et al., 2012 informed that, $77 \%$ of LAB isolates obtained from cheese and sourdough inhibited at least one fungus and $43 \%$ inhibited both $A$. niger and $A$. fumigatus. Our results found a higher percentage occurrence of antifungal $L A B$ isolates in curd and idly batter than paddy grains and tomato. Based on the level of inhibition against both the test fungi, of the 24 isolates six isolates viz., LABT3, LABC2, LABC7, LABP1, LABP2 and LABP3 were selected.

The fungal growth inhibition analysis was carried out for these six antifungal isolates using microplate reader. The isolate LABT3 showed the highest inhibition percentage of about $90.59 \%$ against $F$. oxysporum and 86.69 $\%$ against $A$. flavusand was significantly different from other isolates in its inhibition level to fungi (Table 3 ). The LAB strains isolated from cocoa fermentation were analyzed by microplate reader for their antifungal activity against Penicillium citrinum M6E1TS, $P$. griseofulvum M2BT2, P. griseofulvum S2TC, Aspergillus niger DsfAn, A. fumigatus DsfAf and A. flavus ST2A and found that Lactobacillus plantarum LARB65 showed the highest inhibition percentage ranging from 88 to $100 \%$ against all six target fungi (Ruggirello et al., 2019).

\section{Growth characteristics of the isolate LABT3}

The viable cell population of the isolate LABT 3 was determined by growing in MRS broth with initial $\mathrm{pH}$ of 6.4 at different time intervals. The isolate attained a maximum viable population of about $11.72 \pm 0.98 \log \mathrm{cfu} \mathrm{mL}^{-1}$ at $48 \mathrm{~h}$. At $48 \mathrm{~h}$ the $\mathrm{pH}$ was recorded as $5.16 \pm 0.11$. The $\mathrm{pH}$ of the culture broth was further reduced to $4.09 \pm 0.09$ at $72 \mathrm{~h}$ (Figure 3 ) and a reduction in cell number was noted at this time. Lactobacillus plantarum CCDM 181 attained a viable population of $9.46 \log \mathrm{cfu} \mathrm{mL}^{-1}$ at $18 \mathrm{~h}$ and the $\mathrm{pH}$ of the culture broth was reduced earlier at $18 \mathrm{~h}$ to 4.01 (Horackova et al., 2018).

\section{Abbreviations \\ CFS - cell-free supernatant \\ $\mathrm{cfu}$ - Colony forming units}




\section{CONCLUSION}

The present study was conducted to select naturally occurring lactic acid bacteria with antifungal activity from different food systems. The LAB isolates with antifungal activity was high in fermented foods than in nonfermented foods. Under in vitro conditions the isolate LABT 3 was identified as a potential isolate to inhibit the growth of $A$. flavus and $F$. oxysporum. Since these two fungi produce mycotoxins, the antifungal LAB isolate LABT3 obtained in the present study would be a potent LAB candidate for in situ application in the food system to inhibit fungal growth and detoxification.

\section{Ethics statement}

Nospecific permits were required for the described studies because no human or animal subjects were involved in this research.

\section{Originality and plagiarism}

Weensure that we have written and submitted onlyentirely original works, and if we have used the work and/or words of others, this has been appropriately cited.

Consent for publication

All the authors agreed to publish the content.

Competing interests

There were no conflict of interest in the publication of this content

Data availability

All the data of this manuscript are included in the MS. No separate external data source is required. If anything is required from the MS, certainly, this will be extended by communicating with the corresponding author through corresponding official mail; vijiladauphin@yahoo.co.in

\section{Author contributions}

Idea conceptualization and guidance- - KV; Experiments- CS; Writing-original draft- CS; Writing- reviewing ctediting - KV, CS

\section{REFERENCES}

Barrios-Roblero, C., R. Rosas-Quijano, M. Salvador-Figueroa, D. Gálvez-López, and A. Vázquez-Ovando. 2019. "Antifungal lactic acid bacteria isolated from fermented beverages with activity against Colletotrichum gloeosporioides." Food Bioscience 29:47-54.

Bettache, G., Fatma, A., Miloud, H., \& Mebrouk, K. (2012). Isolation and identification of lactic acid bacteria from Dhan, a traditional butter and their major technological traits. World Applied Sciences Journal, 17(4), 480-488.

Crowley, S., J. Mahony, and D. van Sinderen. 2013. "Current perspectives on antifungal lactic acid bacteria as natural bio-preservatives." Trends in food science \& technology 33 (2):93-109.

De Man, J.C., d. Rogosa, and M.E. Sharpe. 1960. "A medium for the cultivation of lactobacilli." Journal of applied Bacteriology $23(1): 130-135$.

de Souza Sant'Ana, A., A. Rosenthal, and P.R. de Massaguer. 2008. "The fate of patulin in apple juice processing: A review." Food Research International 41 (5):441-453.

Elmabrok, A. , Z. Hassan, K. Hussin, and A. Mokhtar. 2013. "Antifungal activity of Lactobacillus plantarum LABC5 and LAB-G7 isolated from Malaysian fruits." Acta Biologica Malaysiana (2013) 2 (1):22-30.

Gerbaldo, G. A., Barberis, C., Pascual, L., Dalcero, A., \& Barberis, L. (2012). Antifungal activity of two Lactobacillus strains with potential probiotic properties. FEMS microbiology letters, 332(1), 27-33.

Gourama, H., \& Bullerman, L. B. (1995). Inhibition of growth and aflatoxin production of Aspergillus flavus by Lactobacillus species. Journal of Food Protection, 58(11), 1249-1256.

Guo, J., Brosnan, B., Furey, A., Arendt, E., Murphy, P., \& Coffey, A. (2012). Antifungal activity of Lactobacillus against Microsporum canis, Microsporum gypseum and Epidermophyton floccosum. Bioengineered, 3(2), 104-113.

Horackova, S., Novakova, T., Slukova, M., Bialasova, K., Kumherova, M., \& Plockova, M. (2018). Antifungal activity of selected Lactobacilli intended for sourdough production. Applied Food Biotechnology, 5(4), 213-220.

Jard, G., T. Liboz, F. Mathieu, A. Guyonvarc'h, and A. Lebrihi. 2011. "Review of mycotoxin reduction in food and feed: from prevention in the field to detoxification by adsorption or transformation." Food Additives \& Contaminants: Part A 28(11):1590-1609. 
Jeygowri, N., Parahitiyawa, N., Jeyatilake, S., Ranadheera, S., \& Madhujith, T. (2015). Study on isolation of potentially probiotic Lactobacillus species from fermented rice. Tropical Agricultural Research, 26(3), 428-440.

Joint, F.A.O., W.H.O.E.C.o.F. Additives, and O. World Health. 2002. Evaluation of certain mycotoxins in food: fiftysixth report of the JointFAO/WHOExpert Committee on FoodAdditives: World Health Organization.

Lee, J.-Y., C.-J. Kim, and B. Kunz. 2006. "Identification of lactic acid bacteria isolated from kimchi and studies on their suitability for application as starter culture in the production of fermented sausages." Meat science $72(3): 437-445$.

Lucia, M.d. 1994. Agricultural engineering in development: post-harvest operations and management of foodgrains. FAO.

Luz, C. , V. D'Opazo, J.M. Quiles, R. Romano, J. Mañes, and G. Meca. 2020. "Biopreservation of tomatoes using fermented media by lactic acid bacteria." LWT130:109618.

Muhialdin, B. J., Algboory, H. L., Kadum, H., Mohammed, N. K., Saari, N., Hassan, Z., \& Hussin, A. S. M. (2020). Antifungal activity determination for the peptides generated by Lactobacillus plantarum TE10 against Aspergillus flavus in maize seeds. Food Control, 109, 106898.

Pitt, J.I., and A.D. Hocking. 2009. Fungi and food spoilage. Springer New York.

Rajasri, M., P.S. Rao, and K. Kumari. 2014. "Inert dusts better alternatives to manage Angoumois grain moth Sitotroga cerealella in stored rice." Int. J. Sci. Res 3 (10):278-283.

Ruggirello, M., Nucera, D., Cannoni, M. , Peraino, A., Rosso, F., Fontana, M., ... \& Dolci, P. (2019). Antifungal activity of yeasts and lactic acid bacteria isolated from cocoa bean fermentations. Food Research International, 115, 519-525.

Schnürer, J., \& Magnusson, J. (2005). Antifungal lactic acid bacteria as biopreservatives. Trends in Food Science \& Technology, 16(1-3), 70-78.

Shehata, M.G., A.N. Badr, S.A. El Sohaimy, D. Asker, and T.S. Awad. 2019. "Characterization of antifungal metabolites produced by novel lactic acid bacterium and their potential application as food biopreservatives." Annals of Agricultural Sciences 64(1):71-78.

Stiles, M.E. 1996. "Biopreservation by lactic acid bacteria." Antonie van leeuwenhoek 70 (2):331-345.

Walter, P.P., P. Tünde, and P. István. 2015. "Mycotoxins-Prevention and Decontamination by Yeasts." Journal of basic microbiology $55(7): 805-818$.

Tables

Table 1 Population of $L A B$ in different samples

\begin{tabular}{|c|c|c|c|c|c|}
\hline S.No. & Place of collection & $\begin{array}{l}\text { Name of the } \\
\text { sample }\end{array}$ & $\begin{array}{l}\text { Description of the } \\
\text { sample }\end{array}$ & $\begin{array}{l}\text { Population of } \\
\text { LAB (cfu mL-1 }^{-1} \\
\text { or } \text { cfug }^{-1} \text { ) }\end{array}$ & $\begin{array}{l}\text { No. of } \\
\text { Selected } \\
\text { isolates }\end{array}$ \\
\hline 1. & $\begin{array}{l}\text { Central farm, Tamil } \\
\text { Nadu Agricultural } \\
\text { University, Coimbatore }\end{array}$ & $\begin{array}{c}\text { Paddy grains } \\
\text { (ADT 43) }\end{array}$ & $\begin{array}{c}\text { Stored grains (2 } \\
\text { months) soaked for } 12 \\
\mathrm{~h}\end{array}$ & $28.3 \times 10^{4}$ & 5 \\
\hline 2. & Home made & Idly batter & $\begin{array}{l}\text { Rice and black gram } \\
\text { ratio is } 4: 1 \text { and } \\
\text { fermented for } 18 \mathrm{~h}\end{array}$ & $75.2 \times 10^{5}$ & 15 \\
\hline 3. & Uzhavar sandhai & Tomato & Fresh vegetable & $38.6 \times 10^{4}$ & 10 \\
\hline 4. & Uzhavar sandhai & Cabbage & Fermented for 5 days & $62.5 \times 10^{5}$ & 10 \\
\hline 5. & Home made & Curd & Fermented for $12 \mathrm{~h}$ & $83.5 \times 10^{5}$ & 20 \\
\hline
\end{tabular}


Table 2 Antifungal activity of $L A B$ isolates against fungal contaminants by dual plate technique

\begin{tabular}{|c|c|c|c|}
\hline S.No. & Isolate No. & Aspergillus flavus & Fusarium oxysporum \\
\hline 1. & LABT1 & - & ++ \\
\hline 2. & LABT3 & ++ & +++ \\
\hline 3. & LABT4 & + & + \\
\hline 4. & LABT5 & . & ++ \\
\hline 5. & LABT8 & . & + \\
\hline $6 .$. & LABP1 & ++ & ++ \\
\hline 7. & LABP2 & ++ & ++ \\
\hline 8. & LABP3 & + & ++ \\
\hline 9. & LABP4 & + & + \\
\hline 10. & LABB2 & . & + \\
\hline 11. & LABB3 & ++ & . \\
\hline 12. & LABB5 & & ++ \\
\hline 13. & LABB8 & + & . \\
\hline 14. & LABB9 & & + \\
\hline 15. & LABC1 & . & + \\
\hline 16. & LABC2 & + & + \\
\hline 17. & LABC3 & & ++ \\
\hline 18. & LABC4 & + & + \\
\hline 19. & LABC6 & + & + \\
\hline 20. & LABC7 & ++ & + \\
\hline 21. & LABC 8 & & + \\
\hline 22. & LABC10 & 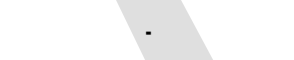 & + \\
\hline 23. & LABC11 & & ++ \\
\hline 24. & LABC15 & ++ & $\cdot$ \\
\hline
\end{tabular}

Note

$++\quad: \quad>2.5 \mathrm{~cm}$ inhibition distance

$+\quad: \quad 1$ to $2.5 \mathrm{~cm}$ inhibition distance

$+\quad: \quad<1 \mathrm{~cm}$ inhibition distance

: No inhibition 
Table 3. Fungal growth inhibition by LAB isolates

\begin{tabular}{|c|c|c|}
\hline \multirow{2}{*}{ LAB isolates } & \multicolumn{2}{|c|}{ Fungal growth inhibition (\%) } \\
\cline { 2 - 3 } & A. Flavus & F. oxysporum \\
\hline LABC2 & $66.20 \pm 0.20^{\mathrm{b}}$ & $75.90 \pm 0.09^{\mathrm{b}}$ \\
\hline LABC7 & $65.50 \pm 0.68^{\mathrm{b}}$ & $42.08 \pm 0.40^{\mathrm{d}}$ \\
\hline LABP1 & $62.53 \pm 0.69^{\mathrm{b}}$ & $40.70 \pm 0.82^{\mathrm{d}}$ \\
\hline LABP2 & $63.53 \pm 0.69^{\mathrm{b}}$ & $78.22 \pm 0.77^{\mathrm{b}}$ \\
\hline LABP3 & $40.78 \pm 0.79^{\mathrm{c}}$ & $71.25 \pm 0.13^{\mathrm{c}}$ \\
\hline LABT3 & $86.69 \pm 0.97^{\mathrm{a}}$ & $90.59 \pm 0.11^{\mathrm{a}}$ \\
\hline
\end{tabular}

Data are mean \pm standard deviation; $\mathrm{a} / \mathrm{b} / \mathrm{c} / \mathrm{d}$ referred to various data within isolates of each fungus

\section{Figures and Structures}

Figure 1: Fungal inhibitory activity of LAB isolates against Aspergillus flavus and Fusarium oxysporum ( 5 days of incubation)

a.

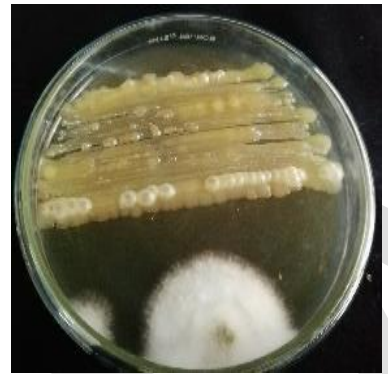

A. flavus + LABT3

c.

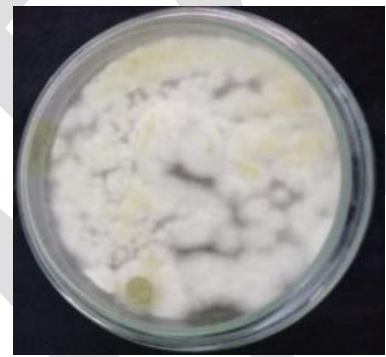

A. flavus b.

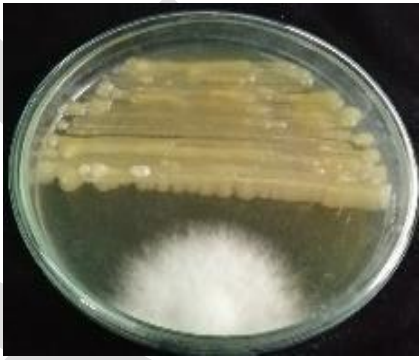

F. oxysporum + LABT3

d.

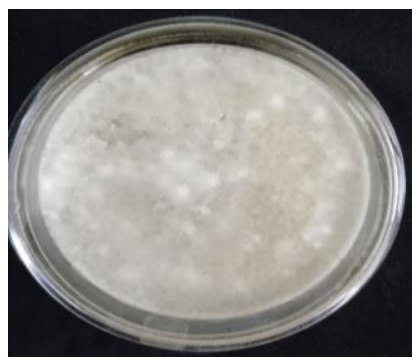

F. oxysporum

Figure 2: Percentage of fungal inhibition by LAB isolates from different samples 


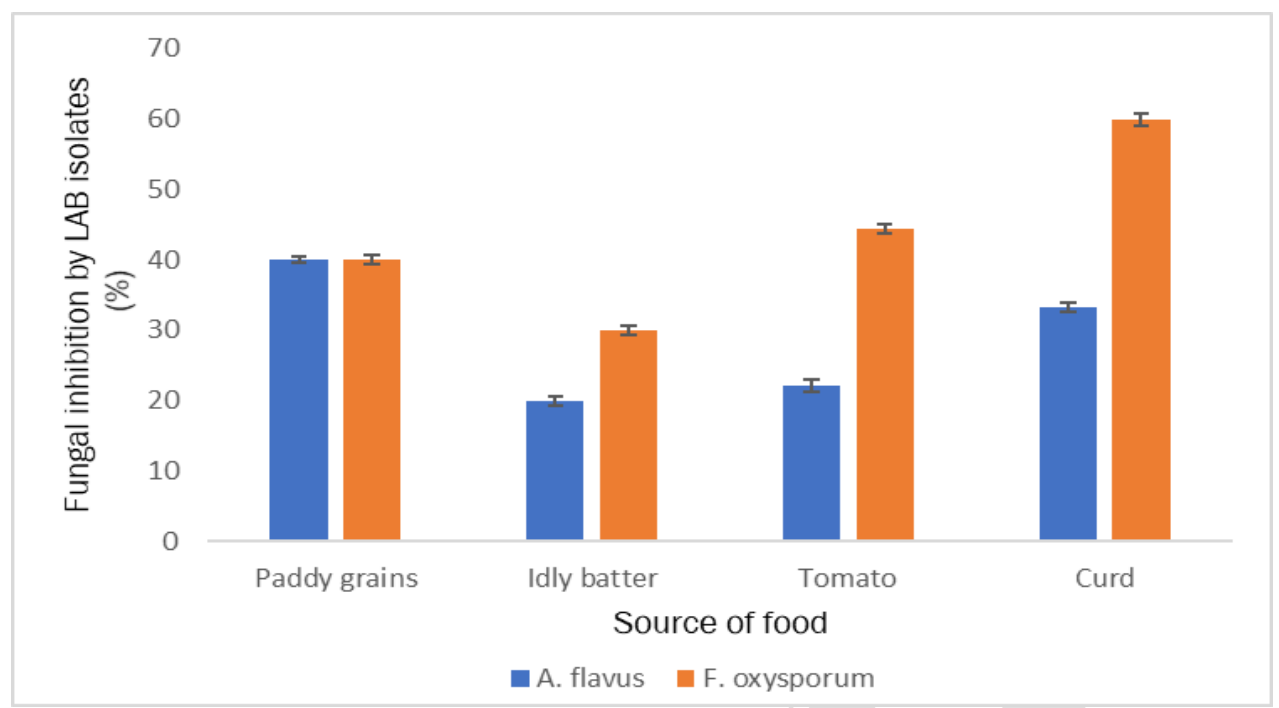

Error bars represent the standard error

Figure 3: Viable cell population of the isolate, LABT3 isolate at different time period

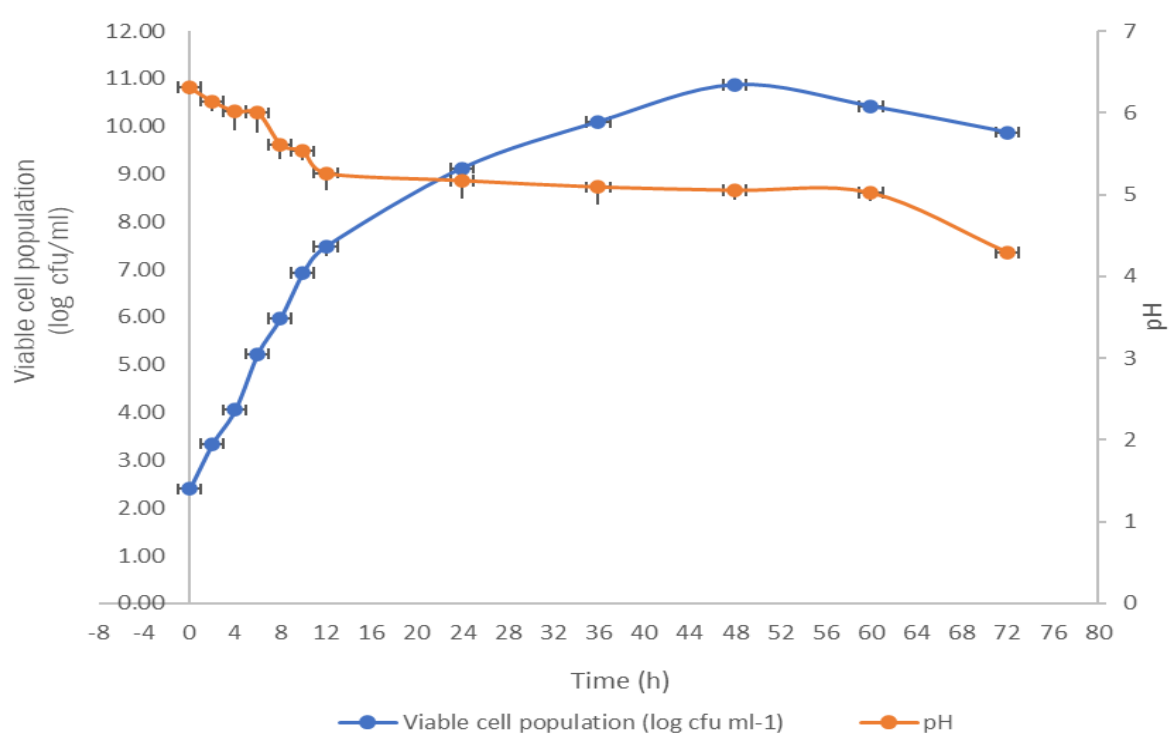

Error bars represent the standard error

Volume $\mathrm{xxx} \mid$ Issue $\mathrm{xxxx} \mid 8$ 